\title{
Hubungan Parental Meta-Emotion dengan Kemampuan Regulasi Emosi Anak Pra-Sekolah
}

\author{
Joana Novena Putri, Fitriani Yustikasari Lubis \\ Universitas Padjadjaran, Indonesia \\ Email: joana19001@mail.unpad@ac.id, fitriani.y.lubis@unpad.ac.id
}

\begin{abstract}
This study aims to determine the relationship between parental meta-emotion and emotion regulation on pre-school kids. In IndonesiaThe two dimensions of parental meta-emotion are emotion coaching and emotion dismissing. The independent variable in this study is emotion coaching and the dependent variable are emotion coaching and emotion dismissing. The sampling technique in this study uses purposive sampling technique with 97 mothers in Bandung City. The measuring instrument used in this study is Emotion Regulation Checklist (ERC) and Maternal Emotion Style Questionnaire (MESQ). The validity and reliability test in this study uses the Cronbach Alpha technique. The result of the validity coefficient on ERC move from 0,339 to 0,953 with reliability coefficient of $a=0,951$ for liability/negativity dimension and 0,948 for emotion regulation dimension. While on MESQ move from 0,317 to 0,697 with reliability coefficient of a $=0,649$ for emotion regulation dimension and 0,747 for emotion dismissing dimension. Based on data analysis, a correlation value between emotion coaching and emotion regulation is 0,139 with a significance level of 0,173 and a correlation value between emotion dismissing and emotion regulation is -0,416 with a significance level of 0,000. This shows that there is not a significant relationship between emotion coaching and emotion regulation, and also there is a significant relationship between emotion dismissing and emotion regulation on pre-school kids.
\end{abstract}

Keywords: parental meta-emotion, emotion regulation, pre-school, kids

\begin{abstract}
Abstrak
Penelitian ini bertujuan untuk mengetahui hubungan antara parental meta-emotion dengan kemampuan regulasi emosi anak pra-sekolah. Terdapat dua dimensi dalam parental meta-emotion yaitu emotion coaching dan emotion dismissing. Variabel bebas dalam penelitian ini adalah emotion coaching dan emotion dismissing. Sedangkan variabel terikat dalam penelitian ini adalah regulasi emosi. Teknik pengambilan sampel dalam penelitian ini menggunakan teknik purposive sampling dengan jumlah sampel sebanyak 97 orang ibu di Kota Bandung. Alat ukur yang digunakan dalam penelitian ini adalah Emotion Regulation Checklist (ERC) dan juga Maternal Emotion Style Questionnaire (MESQ). Uji validitas dan reliabilitas pada penelitian ini menggunakan teknik Alpha Cronbach. Hasil koefisien validitas pada ERC berkisar dari 0,339 sampai dengan 0,953 ) dengan koefisien reliabilitas sebesar $a=0,951$ untuk dimensi liability/negativity dan 0,948 untuk dimensi emotion regulation. Sedangkan, hasil koefisien validitas pada MESQ berkisar dari 0,317 sampai dengan 0,697 dengan koefisien reliabilitas sebesar $a=0,649$ untuk dimensi emotion regulation dan 0,747 untuk dimensi emotion dismissing. Hasil uji hipotesis menunjukkan nilai korelasi antara emotion coaching dengan regulasi emosi yaitu sebesar 0,139 dengan taraf signifikansi 0,173 dan korelasi antara emotion dismissing dengan regulasi emosi yaitu sebesar -0,416 dengan taraf signifikansi 0,000. Hal ini menunjukkan tidak terdapat hubungan antara emotion coaching dengan regulasi emosi dan terdapat hubungan signifikan negatif antara emotion dismissing dengan regulasi emosi pada anak pra-sekolah.
\end{abstract}

Kata kunci: meta-emosi orangtua, regulasi emosi, pra-sekolah, anak

\section{Pendahuluan}

Kemampuan regulasi emosi merupakan kemampuan yang penting untuk kesejahteraan psikologis dan juga kemampuan sosial anak [1]. Regulasi emosi merupakan proses dimana individu mengalami, mengatur, dan mengekspresikan emosinya [2], [3]. Regulasi emosi merupakan proses modulasi kejadian, durasi, dan intensitas dari keadaan perasan internal (baik negatif maupun positif) dan proses fisiologis yang terkait dengan emosi [2], [4]. Kemampuan ini membantu anak untuk memonitor, mengevaluasi, dan memodifikasi reaksi emosionalnya [4]. Kemampuan untuk meregulasi emosi secara efektif merupakan hal yang krusial untuk bertumbuh secara sukses dan diasosiasikan dengan kompetensi sosial, sedangkan ketidakmampuan dalam meregulasi emosi berhubungan dengan permasalahan internalisasi dan eksternalisasi [5], [6]. Perilaku eksternalisasi merupakan perilaku yang bermasalah secara sosial yang biasanya ditunjukkan dengan ketidakpatuhan, melanggar aturan, kemarahan, agresi verbal, kenakalan, peronakan serta perlawanan terhadap lingkungan sosial [7]. 
Sedangkan perilaku internalisasi merupakan permasalahan perilaku yang diarahkan keapda diri sendiri dan dikendalikan secara berlebihan seperti penarikan diri dari sosial, keluhan somatic, kesepian, kecemasan, serta depresi [8].

Anak yang memiliki kemampuan untuk meregulasi emosinya cenderung berperforma baik secara psikologis, sosial, dan akademik [9]. Anak dengan regulasi emosi yang baik juga dapat membentuk pertemanan yang hangat dan terlibat dapat interaksi positif dengan teman sebaya, lebih mudah beradaptasi dengan lingkungan yang baru, dan mengatasi tekanan dengan lebih baik [10]. Sebaliknya, anak dengan regulasi emosi yang buruk memiliki kecenderungan untuk mengalami permasalahan perilaku, mengalami permasalahan kesehatan mental, dan memiliki kesulitan dalam sosial serta akademik [11].

Kemampuan regulasi emosi dipengaruhi oleh 2 faktor yaitu faktor internal dan eksternal [12]. Komponen internal mengacu pada proses neurobiologis dan strategi kognitif yang anak gunakan untuk mengatur emosi mereka seperti shifting attention, cognitive reframing, dan arousal modulation [2]. Sedangkan, komponen eksternal muncul dalam konteks hubungan orangtua dan anak [12]. Kemampuan regulasi emosi pada anak- anak sangat dipengaruhi oleh faktor eksternal [13]. Cara orangtua mengajarkan emosi kepada anak berkontribusi pada ekspresi emosi anak serta reaksi anak terhadap emosi teman sebayanya. Orangtua berperan untuk memberikan bantuan dan arahan kepada anak dalam meregulasi emosinya [14]. Pada masa pra-sekolah, anak membutuhkan dukungan dan arahan yang banyak dari orangtua untuk meregulasi emosinya. Interaksi antara anak dengan orangtua merupakan "tempat pelatihan" untuk kemampuan emosional pada anak [15]. Melalui interaksi antara anak dan orangtua, anak mempelajari cara untuk menghadapi situasi yang kurang menyenangkan dan juga perasaan sedang dirasakan [9], [16], [17].

Salah satu peran orangtua yang berpengaruh pada regulasi emosi anak adalah parenetal meta-emotion [18]. Parental meta-emotion merupakan kumpulan dari perasaan dan juga kognisi yang terorganisir mengenai emosi diri sendiri dan emosi orang lain [19]. Terdapat 2 jenis parental meta-emotion yaitu emotion coaching dan emotion dismissing. Emotion coaching didefinisikan sebagai kesadaran orangtua mengenai emosi dirinya sendiri dan anaknya, dan kemampuan untuk menggunakan kesadaran ini untuk mengajarkan anak mereka dalam mengatasi emosi yang sedang dirasakan [20]. Orangtua yang memiliki pola pengasuhan ini biasanya sadar mengenai emosinya sendiri, dapat mengungkapkan emosi mereka dengan cara yang sesuai, sadar akan emosi dari anak mereka, dan dapat membantu anak mereka mengatasi emosi yang sedang dirasakan, terutama emosi negatif [18], [19]. Sedangkan, emotion dismissive didefinisikan sebagai kurangnya kesadaran orangtua mengenai emosi dirinya sendiri dan anaknya, sehingga orangtua memiliki kemampuan yang kurang dalam menghadapi emosi yang dirasakan anak [20]. Karakteristik dari orangtua dengan emotion dismissive adalah orangtua kurang memiliki kesadaran mengenai dirinya dan anak mereka, takut tidak dapat mengendalikan emosinya, tidak mengetahui teknik untuk mengungkapkan emosi negatif, dan percaya bahwa emosi negatif merupakan refleksi dari kemampuan pengasuhan yang buruk [18], [19].

Saat ini, penelitian mengenai parental meta-emotion masih terbatas meneliti mengenai salah satu dimensi dari parental meta-emotion yaitu emotion coaching. Terdapat beberapa studi yang menyatakan bahwa emotion coaching yang dilakukan oleh ibu berkolelasi positif dengan kemampuan regulasi anak [21], [22]. Ibu diyakini sebagai pihak dari orangtua yang paling sering berinteraksi langsung dengan anak. Di Indonesia sendiri, ditemukan bahwa mayoritas ibu (92\%) menunjukkan emotion coaching pada tingkat rendah. Tingkat emotion coaching yang rendah berpengaruh terhadap ketidakmampuan anak dalam meregulasi emosinya [23]. Berdasarkan penjabaran diatas, penelitian kali ini bertujuan untuk mengetahui hubungan antara parental meta-emotion, baik emotion coaching maupun emotion dismissing, terhadap regulasi emosi anak pra-sekolah.

\section{Metode Penelitian}

Penelitian ini merupakan penelitian kuantitatif korelasional dengan variabel dependent yaitu regulasi emosi (Y) dan variabel independent yaitu emotion coaching (X1) dan emotion dismissing (X2). Populasi dalam penelitian ini adalah ibu dari anak pra-sekolah yang tinggal di Kota Bandung. Metode sampling yang digunakan dalam penelitian ini adalah purposive sampling dengan kriteria responden yaitu: (1) ibu dari anak pra-sekolah, (2) anak berusia 4-7 tahun, (3) anak berada dalam tingkat 
pendidikan pra-sekolah, (4) berdomisili di kota Bandung, dan (5) anak tidak memiliki gangguan perkembangan. Partisipan dalam penelitian ini terdiri dari 97 responden. Alat ukur yang digunakan dalam penelitian ini adalah Emotion Regulation Checklist yang biasa disingkat ERC [24] dan Maternal Emotion Style Questionnaire yang biasa disingkat MESQ [20]. ERC menggunakan format jawaban model likert dengan empat pilihan jawaban dari hampir selalu, kadang-kadang, jarang, dan tidak pernah (contoh pertanyaan: "Anak saya adalah anak yang ceria"). Alat ukur Emotion Regulation Checklist telah ditranslasi dalam bahasa Indonesia serta telah diuji validitas dan reliabilitasnya oleh Christopora Intan (2017). Sedangkan, MESQ diadaptasi ke dalam Bahasa Indonesia oleh peneliti. Proses forward-backward translation dilakukan oleh penerjemah dengan kriteria menguasai bahasa Indonesia dan Inggris. MESQ menggunakan format jawaban model likert dengan lima pilihan jawaban dari STS (Sangat Tidak Setuju), TS (Tidak Setuju), N (Netral), S (Setuju), dan SS (Sangat Setuju) (contoh pertanyaan: "Perasaan sedih merupakan hal yang harus diatasi, dilewati, dan bukan diratapi"). Pengambilan data dilakukan secara daring menggunakan aplikasi google form. Google form terdiri dari beberapa bagian yaitu (1) bagian pembuka, (2) informed consent, (3) data demografi, (4) ERC, dan (5) MESQ.

Tahap analisis dalam penelitian ini terdiri dari uji normalitas, linearitas, dan korelasi. Uji normalitas berguna untuk mengetahui apakah populasi data berdistribusi normal dan akan dilakukan dengan menggunakan uji Kolmogorov-Smirnov. Uji normalitas akan membantu peneliti untuk menentukan jenis uji yang akan digunakan pada tahap selanjutnya. Uji linearitas digunakan untuk mengetahui apakah dua variabel mempunyai hubungan yang linear atau tidak. Dua variabel akan dinyatakan mempunya hubungan yang linear apabila memiliki signifikansi kurang dari 0,05. Uji linearitas akan dilakukan ketika seluruh data dinyatakan berdistribusi normal. Uji validitas digunakan untuk mengetahui sejauh mana ketepatan serta kecermatan suatu alat ukur dapat melakukan fungsi ukurnya. Sedangkan uji reliabilitas digunakan untuk mengetahui sejauh mana alat ukur yang akan digunakan tersebut memiliki taraf ketelitian, kepercataan, kekonstanan, atau kestabilan, sehingga alat ukur tersebut dapat dikatalan reliabel [25]. Data dianalisis dengan menggunakan program SPSS 22. Berdasarkan uji normalitas dan linerilitas maka metode penelitian yang digunakan dalam penelitian ini adalah analisis product moment (pearson) yang digunakan untuk melihat hubungan antara dimensi pada parental meta-emotion dengan regulasi emosi anak.

\section{Hasil dan Pembahasan}

\subsection{Hasil}

Berdasarkan uji chi-square, ERC memiliki validitas yang bergerak dari 0,339 - 0,953 dengan reliabilitas sebesar 0,951 untuk dimensi liability/negativity dan 0,948 untuk dimensi emotion regulation. Sedangkan, koefisien validitas MESQ pada dimensi emotion coaching dengan nilai corrected item-total correlation berkisar antara 0,317 sampai dengan 0,505, dengan reliabilitas 0,649, dan dimensi emotion dismissing dengan nilai corrected item-total correlation berkisar antara 0,416 sampai dengan 0,697, dengan reliabilitas 0,747 . Uji normalitas dalam penelitian ini menggunakan uji Kolmogorov-Smirnov. Data dinyatakan berdistribusi normal jika memiliki nilai signifikasi (p) lebih besar dari 0,05. Berdasarkan hasil pengolahan data dengan menggunakan IBM SPSS 22, maka diperoleh data sebagai berikut:

Tabel 1. Uji Normalitas Parental Meta Emotion dan Regulasi Emosi

\begin{tabular}{lcccc}
\hline \multicolumn{1}{c}{ Variabel } & N & KSZ & P & Sebaran \\
\hline Regulasi Emosi & 97 & 0,72 & 0,200 & Normal \\
Parental Meta Emotion & 97 & 0,73 & 0,200 & Normal \\
\hline
\end{tabular}

Nilai signifikansi pada skala regulasi emosi sebesar $\mathrm{p}=0,200$ dengan $\mathrm{KSZ}=0,72$ yang menunjukkan bahwa nilai $\mathrm{p}>0,05$, artinya sebaran skala regulasi emosi terdistribusi secara normal. Sedangkan, untuk skala parental meta emotion memiliki nilai signifikan sebesar 0,200 dengan $\mathrm{KSZ}=0,73$ yang menunjukkan bahwa nilai $\mathrm{p}>0,05$, artinya sebaran skala parental meta emotion terdistribusi secara normal. 
Tabel 2. Uji Linearitas Parental Meta Emotion dan Regulasi Emosi

\begin{tabular}{llrrr}
\hline N & Df & Mean Square & F & Sig. \\
\hline 97 & 1 & 236,730 & 4,236 & 0,042
\end{tabular}

Berdasarkan tabel diatas, diperoleh nilai $\mathrm{F}=4,236$ engan signifikansi sebesar $\mathrm{p}=0,042$ dengan ketentuan ( $<$ 0,05), artinya varian pada skala Parental Meta Emotion dan Regulasi Diri tergolong linier.

Tabel 3. Hubungan Dimensi Parental Meta Emotion dan Regulasi Emosi

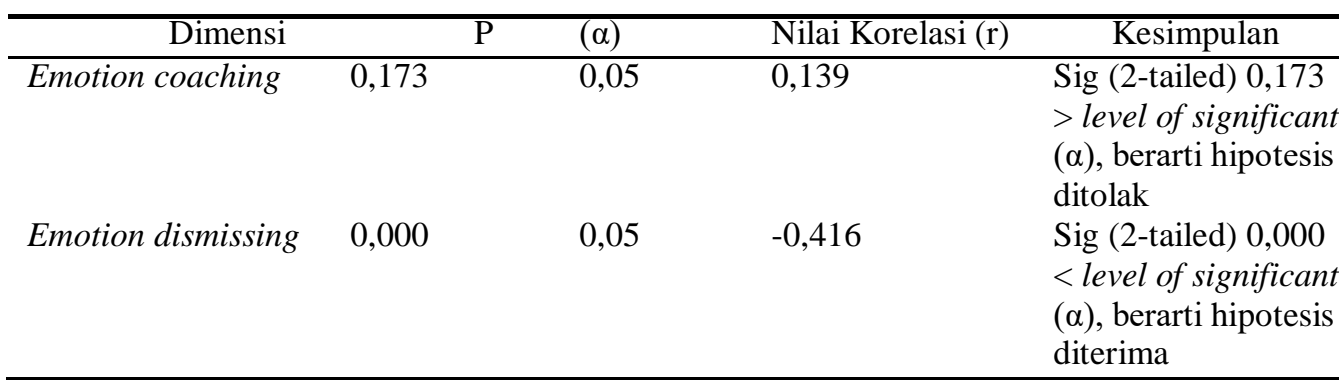

Berdasarkan tabel diatas, maka diperoleh koefisien korelasi antara dimensi emotion coaching dengan regulasi emosi yaitu sebesar $r=0,139$ dengan taraf signifikansi $p=0,173$. Hal ini menunjukkan tidak adanya korelasi antara emotion coaching dengan regulasi emosi anak. Sedangkan koefisien korelasi antara dimensi emotion dismissing dengan regulasi emosi yaitu sebesar $r=-0,416$ dengan taraf signifikansi $\mathrm{p}=0,000$. Hal ini menunjukkan korelasi yang cukup dan berarah negatif yang artinya jika semakin tinggi emotion dismissing yang diterapkan orangtua, maka semakin rendah regulasi emosi yang dimiliki oleh anak. Hal ini diperkuat dengan hasil uji signifikansi dengan bantuan IBM SPSS versi 22.0, didapatkan $\mathrm{p}=0,000<0,05$ level of significant $(\alpha)$, artinya hipotesis diterima, bahwa terdapat hubungan antara pola pengasuhan emotion dismissing dengan regulasi emosi pada anak PraSekolah. Terdapat penemuan serupa yang menyatakan bahwa terdapat hubungan yang negatif antara dismissive parenting dengan kemampuan regulasi emosi anak. Perilaku anak menjadi kurang teregulasi ketika orangtua mereka menggunakan pendekatan dismissing dalam menghadapi kebutuhan emosi anak. Kurangnya kesadaran emosi dan juga dukungan dari orangtua berkontribusi terhadap kemampuan regulasi anak yang rendah (Lagacé-Séguin \& Coplan, 2005).

\subsection{Pembahasan}

Berdasarkan uji korelasi Product Moment (Pearson) yang dilakukan dengan bantuan IBM SPSS versi 22.0 dimana level of significant $(\alpha) 0,05$, diperoleh nilai korelasi antara dimensi emotion coaching dengan regulasi emosi yaitu sebesar $r=0,125$ dengan taraf signifikansi $\mathrm{p}=0,223$ dan koefisien korelasi antara dimensi emotion dismissing dengan regulasi emosi yaitu sebesar $\mathrm{r}-0,427$ dengan taraf signifikansi $\mathrm{p}=0,000$. Artinya, terdapat hubungan negatif antara emotion dismissing dengan tingkat regulasi anak. Namun, tidak terdapat hubungan yang signifikan antara emotion coaching dengan tingkat regulasi anak. Hubungan yang tidak signifikan dengan emotion coaching menggambarkan bahwa orangtua tidak menggunakan emotion coaching dalam menghadapi emosi yang dirasakan oleh anak. Orangtua dengan emotion coaching melihat emosi negatif yang dirasakan oleh anak sebagai kesempatan untuk menjadi lebih dekat dengan anak dan mengajarkan anak cara untuk mengatasi emosi yang sedang dirasakan [19]. Sehingga dapat disimpulkan bahwa orangtua di Indonesia tidak melihat emosi negatif akan sebagai kesempatan untuk menjadi lebih dekat dengan anak dan mengajarkan anak cara untuk mengatasi emosi yang dirasakan.

Adanya hubungan signfikan antara emotion dismissing dengan regulasi emosi berarti orangtua menggunakan emotion dismissing dalam menghadapi emosi negatif anaknya. Orangtua dengan emotion dismissing melihat emosi negatif sebagai hal yang berbahaya dan harus dihindari serta harus 
secara cepat dilewati [19]. Terdapat penelitian yang mengungkapkan bahwa mayoritas ibu (92\%) di Indonesia tidak menyadari emosinya sendiri, tidak dapat mengungkapkan emosi mereka dengan cara yang sesuai, tidak sadar akan emosi dari anak mereka, dan tidak dapat membantu anak mereka mengatasi emosi yang sedang dirasakan (terutama emosi negatif) [23]. Hasil penelitian ini sejalan dengan penelitian yang mengungkapkan bahwa terdapat hubungan antara parental meta- emotion terhadap kemampuan regulasi emosi anak. Ketika orangtua menerapkan emotion dismissing, maka kemampuan regulasi anak akan semakin rendah [19]. Hal ini sejalan dengan penemuan penelitian ini yang mengungkapkan bahwa terdapat hubungan negatif antara emotion dismissing dengan tingkat regulasi anak. Semakin tinggi emotion dismissing pada orangtua, maka kemampuan regulasi emosi anak akan semakin rendah. Sebaliknya, semakin rendah emotion dismissing pada orangtua, maka semakin tinggi tingkat regulasi emosi yang dimiliki oleh anak.

Emotion dismissing berarti orangtua tidak mampu menyadari emosinya sendiri serta emosi anaknya, serta tidak mampu mengekspresikan emosinya dan cenderung tidak merespon emosi negatif yang dirasakan oleh anak. Penelitian membuktikan bahwa responsivitas orangtua berperan penting dalam kemampuan regulasi emosi anak [26], [27]. Hal ini dapat menjelaskan hubungan negatif yang terjadi antara emotion dismissing dengan regulasi emosi yang dimiliki oleh anak karena salah satu dari karakteristik emotion dismissing adalah responsivitas orangtua yang rendah terhadap emosi negatif yang dirasakan oleh anak.

Terdapat penelitian yang menyatakan bahwa budaya berperan penting pada pola pengasuhan [28]. Hal ini dapat menjelaskan penemuan dalam penelitian ini yang mengungkapkan bahwa orangtua di Indonesia menerapkan emotion dismissing. Budaya kolektif yang dimiliki oleh Indonesia dapat menyebabkan orangtua di Indonesia menggunakan emotion dismissing. Pada budaya kolektif, pesan yang disampaikan biasanya bersifat implisit. Oleh sebab itu, orang di Indonesia tidak terbiasa untuk mengekspresikan emosinya. Mayoritas orang di Indonesia hanya diam dan tidak melakukan apa-apa ketika merasakan suatu emosi [29]. Dengan demikian, maka hal tersebut akan berdampak juga pada parental meta- emotion pada orangtua di Indonesia. Selain itu, pada budaya kolektif, emosi didefinisikan sebagai sebuah konstruk sosial yang terbentuk didalam suatu hubungan timbal balik antar individu dengan lingkungannya. Selain itu, terdapat penelitian yang mengemukakan bahwa bagi orang Indonesia, emosi merupakan hal yang negatif, sehingga harus dikendalikan baik-baik supaya tidak mempengaruhi hubungan dengan orang lain sehingga pada akhirnya kehamornisan tetap terjaga [30]. Penilaian bahwa emosi merupakan suatu hal yang negatif dan harus dikendalikan baik-baik ini dapat menyebabkan orangtua menerapkan emotion dismissing yang memiliki karakteristik berupa harapan orangtua yang menganggap bahwa emosi negatif merupakan hal yang buruk dan tidak perlu untuk anak rasakan.

\section{Kesimpulan}

Terdapat hubungan yang negatif antara emotion dismissing parenting style terhadap regulasi emosi anak pra-sekolah. Hal ini berarti semakin orangtua tidak memanfaatkan emosi negatif yang dirasakan anak untuk mengajarkan anak menghadapi emosi yang sedang dirasakan, maka semakin rendah kemampuan anak untuk meregulasi emosinya. Semakin orangtua memiliki persepsi bahwa momen ketika anak sedih ataupun marah bukanlah merupakan kesempatan untuk mendekati anak, tidak meluangkan waktu bersama anak untuk mencoba menyelami perasaannya, dan tidak mencoba mengajarkan anak mengenai cara menyelesaikan suatu permasalahan, maka anak akan semakin tidak dapat meregulasi emosinya. Orangtua di Indonesia cenderung menerapkan emotion dismissing dikarenakan pengaruh dari budaya kolektivisme. Budaya kolektivisme menilai emosi sebagai suatu hal yang negatif sehingga pada akhirnya orangtua kurang mampu untuk menyadari emosinya sendiri serta emosi anaknya, serta tidak mampu mengekspresikan emosinya dan cenderung tidak merespon emosi negatif yang dirasakan oleh anak.

Berdasarkan hasil analisis data serta penarikan kesimpulan diatas, maka penulis memberikan beberapa saran yang berhubungan dengan penelitian ini, yaitu: (1) Peneliti selanjutnya dapat mengukur regulasi emosi dan parental meta-emotion bukan hanya berdasarkan pada alat ukur yang diisi oleh orangtua melainkan juga menambahkan metode seperti observasi dan wawancara. (2) Peneliti selanjutnya juga 
Joana Novena Putri, Fitriani Yustikasari Lubis

Psyche 165 Journal Vol 14 No 02 (2021) 207 - 213

dapat mengambil data bukan hanya dari ibu sebagai pengasuh utama, melainkan data dari pihak ayah, sehingga data yang diperoleh lebih komprehensif. (3) Peneliti selanjutnya juga dapat menggunakan metode cluster sampling sehingga bisa mendapatkan data yang lebih merepresentasikan Indonesia. (4) Perlu dilakukannya pelatihan untuk meningkatkan emotion coaching pada orangtua di Indonesia, terutama untuk menggunakan momen terjadinya emosi negatif sebagai pembelajaran regulasi emosi.

\section{Daftar Rujukan}

[1] K. Shipman, J. Zeman, M. Fitzgerald, and L. M. Swisher, "Regulating Emotion in Parent-Child and Peer Relationships: A Comparison of Sexually Maltreated and Nonmaltreated Girls," Child Maltreat., vol. 8, no. 3, pp. 163-172, 2003, doi: 10.1177/1077559503254144.

[2] N. Eisenberg and A. S. Morris, "Children's Emotion-Related Regulation," in Advances in Child Development and Behavior, vol. 30, no. C, Academic Press Inc., 2002, pp. 189-229.

[3] J. J. Gross, “The Emerging Field of Emotion Regulation: An Integrative Review," Rev. Gen. Psychol., vol. 2, no. 3, pp. 271-299, Sep. 1998, doi: 10.1037/1089-2680.2.3.271.

[4] R. A. Thompson, "Emotion Regulation: A Theme in Search of Definition," Monogr. Soc. Res. Child Dev., vol. 59, no. 2-3, pp. 25-52, Feb. 1994, doi: 10.1111/j.1540-5834.1994.tb01276.x.

[5] K. Stansbury and L. K. Zimmermann, "Relations among child language skills, maternal socialization of emotion regulation, and child behavior problems," Child Psychiatry Hum. Dev., vol. 30, no. 2, pp. 121-142, 1999, doi: 10.1023/A:1021954402840.

[6] J. Zeman, M. Cassano, C. Perry-Parrish, and S. Stegall, "Emotion Regulation in Children and Adolescents," Dev. Behav. Pract., vol. 18, no. 04, pp. 1105-1131, Dec. 2006, doi: 10.1017/S0954579406060536.

[7] E. F. Zulnida, "Hubungan Masalah Perilaku Internalisasi dan Eksternalisasi Dengan Tingkat Kecerdasan Pada Remaja Di Kota Bandung,” J. Ilm. Psikol. Terap., vol. 8, no. 2, p. 119, 2020, doi: 10.22219/jipt.v8i2.12735.

[8] S. Madigan, L. Atkinson, K. Laurin, and D. Benoit, "Attachment and internalizing behavior in early childhood: A meta-analysis.," Dev. Psychol., vol. 49, no. 4, pp. 672-689, Apr. 2013, doi: 10.1037/a0028793.

[9] A. S. Morris, J. S. Silk, L. Steinberg, S. S. Myers, and L. R. Robinson, "The role of the family context in the development of emotion regulation," Soc. Dev., vol. 16, no. 2, pp. 361-388, May 2007, doi: 10.1111/j.14679507.2007.00389.x.

[10] J. . Shonkoff and D. A. Phillips, From Neurons to Neighborhoods. National Academies Press, 2000.

[11] C. J. M. Buschgens, M. A. G. Van Aken, S. H. N. Swinkels, J. Ormel, F. C. Verhulst, and J. K. Buitelaar, "Externalizing behaviors in preadolescents: Familial risk to externalizing behaviors and perceived parenting styles," Eur. Child Adolesc. Psychiatry, vol. 19, no. 7, pp. 567-575, 2010, doi: 10.1007/s00787-009-0086-8.

[12] N. A. Fox and S. D. Calkins, "The development of self-control of emotion: Intrinsic and extrinsic influences," Motiv. Emot., vol. 27, pp. 7-26, 2003, doi: https://doi.org/10.1023/A:1023622324898.

[13] L. Steinberg, R. Dahl, D. Keating, D. J. Kupfer, A. S. Masten, and D. S. Pine, "Psychopathology in adolescence: Integrating affective neuroscience with the study of context: Developmental neuroscience," Wiley, 2006, pp. 710-741.

[14] S. . Denham, Emotion Development in Young Children. New York: Guildford Press, 1998.

[15] G. S. Ashiabi, "Promoting the emotional development of preschoolers," Early Child. Educ. J., vol. 28, no. 2, pp. 79-84, 2000, doi: 10.1023/A:1009543203089.

[16] P. M. Cole, T. A. Dennis, K. E. Smith-Simon, and L. H. Cohen, "Preschoolers' emotion regulation strategy understanding: Relations with emotion socialization and child self-regulation," Soc. Dev., vol. 18, no. 2, pp. 324-352, May 2009, doi: 10.1111/j.1467-9507.2008.00503.x.

[17] F. Jabeen, M. Anis-ul-Hawue, and N. Riaz, "Parenting styles as predictors of emotion regulation among adolescents," Pakistan J. Psychol. Res., 2013.

[18] J. Gottman and J. DeClaire, The Heart of Parenting. London: Bloomsbury Publishing, 1997.

[19] J. M. Gottman, L. F. Katz, and C. Hooven, "Parental meta-emotion philosophy and the emotional life of families: Theoretical models and preliminary data.," J. Fam. Psychol., vol. 10, no. 3, pp. 243-268, 1996, doi: 10.1037/0893-3200.10.3.243.

[20] D. G. Lagacé-Séguin and R. J. Coplan, "Maternal emotional styles and child social adjustment: Assessment, correlates, outcomes and goodness of fit in early childhood," Soc. Dev., vol. 14, no. 4, pp. 613-636, 2005, doi: 10.1111/j.1467-9507.2005.00320.x.

[21] J. N. Cunningham, W. Kliewer, and P. W. Garner, "Emotion socialization, child emotion understanding and regulation, and adjustment in urban African American families: Differential associations across child gender," Dev. Psychopathol., vol. 21, no. 1, pp. 261-283, 2009, doi: 10.1017/S0954579409000157.

[22] B. H. Ellis, E. Alisic, A. Reiss, T. Dishion, and P. A. Fisher, "Emotion Regulation Among Preschoolers on a Continuum of Risk: The Role of Maternal Emotion Coaching," J. Child Fam. Stud., vol. 23, no. 6, pp. 965974, Aug. 2014, doi: 10.1007/s10826-013-9752-z. 
[23] Y. Wandansari, "Emotion Coaching Oleh Ibu Pada Anak Prasekolah,” J. Experentia, vol. 8, 2020.

[24] A. Shields and D. Cicchetti, "Emotion regulation among school-age children: the development and validation of a new criterion Q-sort scale.," Dev. Psychol., vol. 33, no. 6, pp. 906-916, 1997, doi: 10.1037/00121649.33.6.906.

[25] S. Azwar, Penyusunan Skala Psikologi, 2nd ed. Yogyakarta: Pustaka Pelajar, 2005.

[26] K. Brenning, B. Soenens, S. Van Petegem, and M. Vansteenkiste, "Perceived Maternal Autonomy Support and Early Adolescent Emotion Regulation: A Longitudinal Study,” Soc. Dev., vol. 24, no. 3, pp. 561-578, Aug. 2015, doi: 10.1111/sode.12107.

[27] K. Kim and R. P. Rohner, "Parental Warmth, Control, and Involvement in Schooling," J. Cross. Cult. Psychol., vol. 33, no. 2, pp. 127-140, Mar. 2002, doi: 10.1177/0022022102033002001.

[28] D. Haslam, C. Poniman, A. Filus, A. Sumargi, and L. Boediman, "Parenting Style, Child Emotion Regulation and Behavioral Problems: The Moderating Role of Cultural Values in Australia and Indonesia," Marriage Fam. Rev., vol. 56, no. 4, pp. 320-342, 2020, doi: 10.1080/01494929.2020.1712573.

[29] A. P. Kurniawan and N. U. Hasanat, "Perbedaan Ekspresi Emosi Pada Beberapa Tingkat Generasi Suku Jawa di Yogyakarta," J. Psikol., vol. 34, no. 1, pp. 1-17, 2015, doi: 10.22146/jpsi.7086.

[30] J. E. Prawitasari, "Mengenal Emosi Melalui Komunikasi Nonverbal,” Bul. Psikol., vol. 3, no. 1, pp. 27-43, 2016, doi: 10.22146/bpsi.13384. 